This is the accepted version of the following article:

Palat Narayanan N (2020) The Delhi Bias: knowledge hegemony of India's slum governance. Singapore Journal of Tropical Geography 41(1): 105-119. DOI: 10.1111/sjtg. 12306.

It has been published in final form at https://doi.org/10.1111/sjtg.12306 .

\title{
The Delhi Bias: knowledge hegemony of India's slum governance
}

\author{
Nipesh Palat Narayanan \\ Department of Sociology, University of Colombo, Sri Lanka \\ Australia India Institute, University of Melbourne, Australia \\ Correspondence: Nipesh Palat Narayanan (email: nipesh.ar@gmail.com)
}

\begin{abstract}
Slum eradication has been a concern in South Asian cities since the colonial times. Legislation and policies are being framed both out of national desires and international strategies. However, very little is being studied on how these legislation and policies come into being, specifically geography's influence in their formulation. The article analyses parliamentary debates from India (Rajya Sabha, 1953-2014), and outlines the process of historical, political, and institutional dominance of Delhi. It shows that the slum legislation and policies in India are formulated by abstracting cases from the Delhi slums. This knowledge hegemony of Delhi is discussed within the growing consideration towards urban theory's southern shift, which puts the Southern cities (megacities) as underdogs. The paper argues that at a regional level, these megacities exert the same hegemony that the southern theory wants to avoid. The results argue towards broadening the southern theory and ordinary city discussions.
\end{abstract}

Keywords: slum policy, parliamentary debates, India, knowledge hegemony, southern theory 


\section{Introduction}

The then Indian president Pratibha Devisingh Patil, in a 2009 joint parliamentary session, announced her government's plan to make India slum-free in the next five years (Patil, 2009). This statement, although never achieved, resonates with the aspirations of various countries across the globe (Huchzermeyer, 2010; Roy, 2014). The desire to eliminate slums is not new, neither is the academic interest in this process: from critiquing the usage of the term 'slum' (Gilbert, 2007), to exclusionary policies (Berner, 2000; Datta, 2012; Paul, 2006), to the impossibility of this desire (Koster \& Nuijten, 2016) has extensively been researched. However, there is a literature gap in illustrating the influence of geographical considerations during the formulation of slum legislation and policies.

Informality, poverty, and poor housing are personified in the physicality of the slums (Arabindoo, 2011) by the state, to act. Furthermore, it has been argued that the slums or the poor housing conditions are a result of larger socio-economic processes (Perlman, 1979), i.e., slums are just a symptom of inequity and not the cause. The state, however, has been framing policies to create slum-free cities by draping it with the poverty mitigation agenda. Such policy formulations have two aspects. First, as the problems in slums results from larger developmental issues leading to inequity, it becomes theoretically impossible to be slum-free unless these larger socio-economic developmental issues are initially catered for. Second, for a policy formulation, the 'demographic and theoretical construct' (Rao, 2006: 231) of slums need to be abstracted to concrete issues to be dealt with by the state. That is, how does the state construct the idea of a typical slum to formulate legislation and policies? The first aspect leads to a constant policy renewal due to its inbuilt perpetual failure and the second aspect points to the power geometry (Massey, 1993) of cities, which dominates the policy framework. The article builds on the second aspect by outlining how slum policies in India are formulated by universalizing cases and learning, from Delhi slums. It shows how the control of Central Government over Delhi and the problematization of slums therein has led to a Delhi bias in India's slum policy and legislation domain.

The article intends to test the boundaries of southern theory (Connell, 2011) and ordinary city (Robinson, 2006) discussions. The footing of ordinary city discussions is the critique of the global city model (Robinson, 2006). It criticizes the domination of certain cities because of their higher ranking, achieved by modulating a larger global capital share. It argues against projecting only certain economically important cities as the crucible of urbanism and suggest studying ordinary cities. However, global capital flow is not the only means for domination and as I will show in this article, policy hubs and models like Delhi, dominate using alternate means. It therefore, opens up the possibility of looking at hierarchies beyond capital flow and exploring all cities as ordinary. Furthermore, the southern theory discussions (Connell, 2011; Parnell \& Robinson, 2012; Watson, 
2009) are based on a similar critique of western cities (mainly North American and European cities). It is argued that the idea of urban, in urban theory, is based on this small sample of western cities and is falsely rendered as universal. However, we can see universalization tendencies at a regional level as well, and cities which were rendered as outside of the global idea of urban, becoming a model at a regional level. The article is thus situated at the crossroad of two tasks, first to broaden the boundaries of the southern theory and ordinary city debates, and second, to build a causal network, of factors other than the economic ones, to explain the hegemony of certain cities within sub-global regions.

The article analyses slum-related debates from the question-answer session of the Indian parliament's upper house-Rajya Sabha. These 1228 debates were extracted from the Rajya Sabha official online repository using the keyword 'slum' (using English and regional language variants) from 1953 (the first session) until 2014 (the last session of a finished government). Each of these debates were individually coded and detailed decadal reports of the results were prepared. The paper uses these results, but is structured with a different periodization. All the debates cited in this article have a link to the repository position in the references. This was complemented with national slum legislation, policies, and interviews with government officials carried out during a six-month fieldwork in Delhi in 2015 and 2016. The arguments are structured in three conceptual eras, based on Central Government's (Union/Federal Government's) funding situation. The first era is from 1953 until 1964, where there was a direct funding allocation from the Central Government to the State Governments, for slum clearance programmes. The second spans 1964 until 1996, when (i) the funds targeted towards the slums were compiled in 'block allocations', and (ii) the State Governments were given 'freedom to choose' the modalities of spending. The third era is from 1996 until 2014, when the Central Government moved to a more neoliberal demand driven funding mode.

I will develop the arguments using three interrelated conceptual frameworks, with respect to the historical, political, and institutional context. The historical context refers to Delhi's historical development, as India's capital. The political context refers to the city being the Central Government's seat, as well as larger Central Government control over the city (compared to other Indian cities). Finally, the institutional context refers to the institutional density within the city and the presence of parliamentarians, which renders Delhi more accessible for comprehension and implementation mechanisms.

The results are tied together to answer the broader concern of how certain cities dominate the knowledge production ecosystem. It shows how, the experiences of Delhi slums are abstracted to a typical case for national level legislation and policies. It further illustrates the causality of this Delhi bias by outlining the historical progression of parliamentary debates. The article, thus contributes to the wider literature on southern theory and ordinary city (Connell, 2011; Robinson, 2006) via 
discussing the concerns at a different scale, as well as broadens the debates concerning informality in India (Baviskar, 2003; Bhan, 2016; Dupont, 2008; Ghertner, 2015).

\section{Provincializing ordinary cities and the southern theory}

Knowledge production is inherently under the realm of (human) politics. Leitner and Sheppard (2016) argue that all knowledge is shaped by context and is local. However, they argue, this knowledge production ecosystem, leads to a situation where certain theories emerge as dominant, propagating a hegemonic monist knowledge - 'a knowledge claim that becomes accepted as the only plausible account of a phenomenon' (Leitner \& Sheppard, 2016: 230). They argue that this process of knowledge production is political, and that to counter this hegemony and universalization, we need to provincialize our understanding.

This hegemony of knowledge systems is further highlighted by Chakrabarty (2000). He illustrates how, for a history to be pertinent, it is commonly perceived to need links to the history of Europe. The European or western history is portrayed as universal and other histories need to project themselves as yet another episode of this universal history. Contrarily, while writing the European history, it need not draw similar links from elsewhere. Thus, he argues towards provincializing Europe (history) for the other provincial histories to remain relevant, i.e., to render European history as a provincial one, as just a European history rather than a universal one.

In urban theory, challenges to knowledge production hegemony has led to two main research clusters - ordinary cities and southern theory. Both these clusters are based on the critique of hegemonic urban knowledge being produced in the west and deliberate the means to counter this domination when it travels outside the western context. Connell (2011), for example, outlines the development of sociological thought and illustrates how theory, although some having considerable empirical base in southern countries, have a western bias. Using the taxonomy of metropolitan (i.e., western or northern) and periphery (which is the global south), she argues that the theory building project has had a metropolitan bias. Similarly, Robinson (2006) outlines, how being modern, is essentially rendered as being western, and how this approach decrees many cities as parochial. Therefore, she argues towards a comparative approach to develop new epistemologies in understanding the urbanization in the non-western cities.

Amin and Graham (1997) and later Robinson (2006) critiqued the global city debates, which led to a call for an ordinary city investigation, a model away from the global city analysis. Global city literature originates from the global capital flows and competitiveness of the cities. It inherently ignores the vast majority of cities as an anomaly to the western norms of being urban. The 'interest' of ordinary cities discussions was to counter these hegemonic processes laid out by the global city 
model. Thus, the ordinary city debates argue to develop epistemological breakthroughs in understanding the urban beyond a global city matrix, i.e., beyond the reasoning of global capital flows. However, this endeavour leaves other geographical factors out, which leads to the hegemonic status of certain cities. The hierarchy and hegemony of certain cities in conceptualizing the urban are not just limited to its influence on global capital, e.g., Delhi's control over global capital (or slum population share) in India is comparatively lesser than other Indian cities like Mumbai, yet I will show how Delhi becomes a dominant model for conceptualizing Indian slums. To broaden the knowledge hegemony critiques of ordinary city discussions, therefore, it is important to incorporate a broad-ranging geographical analysis. That is, to critique and counter the formation of city hierarchies beyond global capital flows whilst exploring hegemonic cities themselves as ordinary, in terms of their slum landscapes and their capacity to act as policy hubs.

The call for a southern theory (Comaroff \& Comaroff, 2012; Connell, 2011; de Satgé \& Watson, 2018; Parnell \& Robinson, 2012) arises from the critique of western theoretical developments, which is not applicable in the vast majority of urban agglomerations across the globe, yet portrays itself as universal. Herein the west becomes the metropolis from where the theory is constructed. The periphery becomes the means to collect data to verify the theories built in the metropolis, i.e., the concerns of the metropolis become the concerns of the periphery. Consequently, the knowledge produced in the periphery is rendered parochial or ignored altogether unless it builds on the metropolitan concerns (Connell, 2011). Thus, cities like Delhi become a periphery to theories developed in the metropolis (west). However, with this paper, I intend to further broaden this critique to the periphery, by highlighting the regional metropolises within the global periphery.

I take two different approaches of southern theory and ordinary city in this article, to develop their specific claims regarding knowledge hegemony. The ordinary city discussions provide us with the tools to critique and counter the formation of hierarchies by the cities, but not to consider noncapital hierarchies that influence ordinary cities. Additionally, the southern theory discussions provide us with the tools to investigate and critique the universalization of a specific knowledge system, albeit I do it at a regional scale in the periphery. The article, first, showcases the construction of hegemony (of Delhi) via an ecosystem of knowledge production, and second, how this hegemonic knowledge is universalized (in a national policy context). It argues towards the need to provincialize these discussions, not to counter the global hegemonies, but to speak from and explore regional ones. Thus, not only conceptualizing the south as a 'metaphor' that 'represents the embeddedness of knowledge in relation of power' (Patel, 2019: 32) but rendering the north in the same light. Correspondingly, to understand the knowledge-power relations beyond the global scale and hegemony of the EuroAmerican knowledge production. 
Taking the Delhi case, I argue that (i) there exists a process of knowledge production which puts certain cities at the centre, thereby making a case for geographical considerations within the ordinary city model (of resistance), and (ii) there are metropolises within the periphery, extending the southern theory concerns to the global periphery itself. To read beyond global capital and metropolitan dynamics, we can look at the manifesto laid out by Sheppard et al. (2013), which suggests that these plural causal factors could be accounted for via provincializing. For them, provincializing incurs 'identifying and empowering new loci ... from which to speak back against, thereby contesting, mainstream global urbanism' (Sheppard et al., 2013: 895), albeit without defining what constitutes mainstream. If, to provincialize is to speak back against universalizing tendencies, then this process should definitely need not take the urban, as a singular process and at a global scale. Of the multiple processes and aspects that constitute the urban, I will now focus on slum policies as an alternate locus herein.

\section{The slum policy discussions and the southern turn}

The policy discussions do not distinguish between informality and slums. Contrarily, they use the suffix 'settlement' to equate informal settlements and slums as undesirable habitats (United Nations (2016); United Nations (1976); United Nations (1996). Furthermore, the academic literature on slums or related policies can be categorized into three broad clusters, with overlapping informality discussions. First, that of state actions, where implications and rationality of government actions are being discussed, including policies' efficacy and effects (Bhan, 2013; Datta, 2012; Legg, 2006a; Mahadevia, 2006). Second, the reading of citizen activism, where these government actions are supported or circumvented (Baviskar, 2003; Dembowski, 2001; Ghertner, 2015). Finally, that of situated studies, where ethnography of practices being indulged by informal actors and slum dwellers are enumerated (Mahadevia, 2010; McFarlane, 2012; Palat Narayanan, 2019). This fluid conceptual categorization is not mutually exclusive, but nonetheless, shows the lack of discussions on the power dynamics of cities during the policy formulations. It is the policy critique or its subversion and effects that are largely the subject of inquiry when dealing with slums, and not its making or bearings on its making. Scholars like Legg (2006a) have discussed the effects on policy in colonial Delhi and this paper takes this further at a national level by focussing exclusively on the democratic policy formulations in the parliament.

Slums have had a history of being negatively connoted, especially indicating an incompetent governance. Therefore, when it comes to urban imagination, erasing slums has always been the priority of the various governments. Rao in her work discusses that the idea of slum, challenges the very image of the modern metropolis: 
"The slum — as a demographic and theoretical construct — straddles the conceptual and material forms of city-making that are challenging the imaginary of the modern city (Rao, 2006: 231).

Therefore, when city making is under discussion, the slum inevitably becomes part of that discussion, in which slum-free becomes a quintessential trope for the city to be modern. The 'modern' here, as Robinson (2006) discusses, emanates from the western city model. When Delhi aspires to be London or Singapore (Ghertner, 2015), there is a clear aspirational image to work towards, making slum-free cities being its first step. However, when this politics of images (Baviskar, 2013) is confronted with the task of eliminating slums, the slums present itself with all the real-world complexities and diversities. It becomes easy for a city to identify what it wants to be (a copy of the modern/western metropolis), however faces a road block when typifying the slums whose removal is quintessential, to be modern. In such a situation, the state, beyond the world of the hegemony of what it is to be urban, looks within, to abstract a typical slum for the task of eliminating it. This article outlines knowledge hegemonies around making of this typical slum for policy deliberations.

The search for the typical slum, illustrates the power geometries of agglomerations within India, a quintessentially provincial model of hegemony and hierarchy. Thus, I discuss a case of knowledge hegemony, beyond the notions of global hegemony of what is to be urban, towards a provincial model created via looking within to define slums. An inquiry at this scale outlines the process by which certain cities are placed at the centre and how knowledge hegemonies are created. I take Lawhon and Truelove's (2019: 9) proposition on southern theory, 'as a term and device necessary for the wider analytical project of deconstructing knowledge-power relations'. It therefore is critical to look for such phenomenon beyond the colonially constructed idea of the world (Jazeel, 2014; Perera, 1998; Radcliffe, 2017) and vary the scale.

\section{Commencing the Delhi story-1953-1964}

With India's independence (1947), the erstwhile British territory was divided into two countries, Pakistan (East and West) and India. People migrated from and to, both the newly formed countries. A large number of people arrived to the Union Territory of Delhi from West Pakistan and squatted on empty public buildings or rented tenements in Old Delhi. As Pandey (2001: 122) termed it, Delhi became a 'partition city' with 'partition refugees (not including the local Muslims) still [by 1951] [accounting] for 28.4 per cent of the total population of the city'. With the refugee crisis on the priority list and the governance of Delhi under the Central Government, the Delhi housing crisis became a national issue.

The housing crisis in Delhi added to the already existing congestion concerns of Old Delhi, which were issues that arose much before India's independence (cf. (Legg, 2006b)). New Delhi was 
inaugurated as British India's capital in 1931, and by 1937 a committee headed by A P Hume was constituted to look into the congestion issues of Old Delhi. Thus, much before 1947, Old Delhi had been bestowed with the title 'slum'. However, there were two noteworthy aspects to the postindependent refugee housing crisis, both of which were largely Delhi specific. First, the illegal occupation of public buildings and second, the deteriorating and dense living conditions in Old Delhi. Undertaking the first aspect, the Central Government came up with the Public Premises (Eviction) Act 1947, empowering itself to evict those occupying public buildings. This act was changed in 1950, encompassing the whole of India under its jurisdiction (Chanda, 1958), thus paving way for a series of Delhi centred legislations later. The second aspect of deteriorating living conditions in Old Delhi was more complicated because of its occurrence in the privately owned Katras. Katras are mixed-use residential cum commercial units developed historically during the Mughal era. The owners found it lucrative to divide their Katras into smaller units and rent it out, to as many people as possible. As the demand was high (both due to the refugee situation as well as internal migration), the Katras became denser and this raised debates in the Rajya Sabha.

The concerns relating to Katras were framed as a public health issue. However, due to nonexistent building regulations at the time, and Katras being on private land, there was very little the government could do to mitigate the situation. For the government to be able to act on issues of Katras, The Slum Areas (Improvement and Clearance) Bill, 1956 (henceforth the 1956 Act) was introduced (which was passed by the parliament to become a law). Introducing the bill, the then Home Minister's statement outlined the concerns as:

Well, one can well imagine the conditions which these people have to reconcile themselves to, and the consequences - almost disastrous - that must be prevailing in these areas... Under this Bill, Sir, orders can be passed for the clearance of a slum when it has buildings which are not fit for habitation. When there are no amenities and when those who are forced to find accommodation there, live a life worse than a dog's life, it is necessary to take effective measures (Ballabh Pant, 1956: 2974-5).

The 1956 Act focused on a specific Delhi problem and provided the government with a legal tool to intervene on private properties (specifically Old Delhi Katras). Land in India, and therefore the issue of slums too, are under State Government purview i.e., the Central Government cannot legislate slum-related regulations for the states. However, the 1956 Act was portrayed as a model legislation for various states to copy. The assertion from the Central Government and State Government's lack of interest/capacity led the 1956 Act to be readily copied without much change by various states in India (cf. (Harriss-White et al., 2013; Ramanathan, 2005)). Such copied Acts brought a governmental body regarding slums, commonly called the Slum Board in various states. The Slum Board could declare any area as a slum (there was no definitive definition of 
a slum) then demolish and rebuild it using funds from the land owner. Thus, the first slum-related legislation in India, which was exclusively designed to tackle the Katras' issues of Delhi, was copied elsewhere without much change.

Throughout this era, almost all the states (except for Delhi) could not spend slum clearance money allocated to them by the Central Government. This lapse was largely because the funding was structured using the Delhi experience. The states were given a part (almost 75 per cent) of the expense as a mixture of subsidy and loan by the Central Government, and the State Government was supposed to add the rest as subsidy. As the States had other priorities, their allocations to the slum clearance projects (including social housing) were much lower than that given by the Central Government, and consequently, this lapsed the budget every year (Narayan, 1964).

Delhi, on the other hand, was governed by the Central Government, making it the largest consumer of slum clearance funds (Sherkhan, 1964). This utilization of funds was further facilitated by engagement with professional bodies of Delhi during policy discussions, due to their geographical proximity. For example, the Slum Clearance Committee, headed by the then Indian Law Minister, looking at the slum situation across India, had only one professional body, which was the Town Planning Organization of Delhi (Naik, 1958). The successful utilization of funds in Delhi was judged as a governance achievement. The funding by the Central Government for slum clearance was created due to its specific privileged position and it rendered the issue of slum clearance prevalent in Delhi (which was under its purview) as universal across India. However, the State Government's priorities, which were other than slum clearance, were trivialized in slum-related discussions. Thus, the issue of other cities not utilizing the funds was premised on governance failure and not on the failure of Delhicentric policies. At a global scale, southern cities are seen as parochial due to their deviance from metropolitan urban theory, and similar to the Delhi case, the blame is laid on governance failure.

The 1956 Act was aimed at demolishing slums and rebuilding quality (decongested) housing for the inhabitants. As the slum rebuilding process could technically only accommodate a fraction of the earlier residents (due to density regulations), there was a need for more housing, hence more land. Delhi was faced with increasing population, and land prices were surging. The increase in land prices were hampering the slum clearance projects in Delhi. Consequently, the Central Government made plans to acquire as much land as possible. The idea was that, if the government owns the majority of the land, then social housing will be easier and cost-effective. In a letter to the Chief Ministers of the states, the then Prime Minister Jawaharlal Nehru wrote in 1959:

In every great city, there is a tendency for speculation in land. The right course is for the State or the Corporation to buy up a good deal of land and thus control the speculation as the city grows. This will also help in planning later (Dhage, 1960: 1089). 
The idea of large-scale land acquisition was envisioned for all Indian cities; nonetheless, Delhi was the only successful case of implementation. This was primarily due to the existing institutional structure of the Delhi Development Authority (DDA). DDA under the control of Central Government, operational since 1957, was entrusted with land acquisitions in 1961. Land was acquired though DDA and it became the largest land owner in Delhi. DDA had special interest in the early 1960s to acquire land (as opposed to institutions in other cities), because the first Delhi master plan was under preparation and its implementation (to be carried out by DDA) required public land.

The focus on buying more land resulted in the failure to timely use it for the acquired purposes. Consequently, the slums that came thereafter happened to be on public land. The slums which in the 1950s were rendered as public health issues were now being pictured as parasites squatting on public land, in the Rajya Sabha. The Slum Act 1956, mandated land owners (with the private Katra owners in mind) put money into rebuilding slums. Consequently, demolishing slums on its own land became an expensive proposition for the Government to bear; thus resulting in a sharp decrease in the number of areas declared as slums as per the 1956 Act.

In this section, we saw how the slum was understood from the cases of Delhi Katras. Furthermore, the national parliament being in Delhi and legislating for it, made the Delhi case be read as universal. The institutional proximity of professional bodies in Delhi, the ease of implementation via usage of funds, and the tailormade legislation, helped Delhi to become typified as a model. The knowledge emanating from Delhi regarding slums became the source for policy formulation, thus making it the metropolis and rest of India, its periphery.

\section{Block allocation phase-1964-1996}

Until 1964, the funds allocated by Central Government to the State Governments for slum clearance projects were not fully utilized. In 1964, the Central Government changed its allocation scheme and clubbed all the grants as 'block allocation'. Which meant that the Central Government would allocate a block grant and the State Government could then decide how to utilize it.

We have already seen in the previous section that the majority of the Delhi slums were, by now, on public land. The Rajya Sabha discussion on slums, in this era, had moved away from the 1956 Act of demolishing and rebuilding, to the realm of realpolitik. Housing all the slum dwellers generally came to be understood as a distant aim which would not be achievable in the near future. In 1972, the Central Government launched the scheme called 'Environmental Improvement of Urban Slums' (EIUS). It aimed at providing basic amenities to slums, which again was a direct derivative of the Delhi case. The Central Government could not demolish the Delhi slums, because as per the 1956 Act, the land owner (government here) would have to pay for better housing. Therefore, the Delhi 
case made it logical to have status quo and provide basic civic amenities instead. In other cities where the slums were not on public land, it made economic sense, to squat on environmentally protected or other public lands and thereafter demand civic amenities via EIUS. Thus, such a Delhi-centric policy led to land-grabbing and development of more slums in other cities, usually in compliance with local politicians. Such practices were documented in big cities like Mumbai (Chatterji, 2005; Das, 2003; Weinstein, 2008) and Chennai (Joshi \& Kale, 2013).

Members of the Rajya Sabha come from different states in India. However, the issue of slums in their respective states rarely got discussed. Contrarily, Rajya Sabha members found it legitimate to discuss more Delhi issues, as Delhi was under its purview. As a parliamentarian from Bihar notes:

Indeed some of my friends asked me how I had become interested in the matter of Delhi. I can only say that unfortunately I have become interested in Delhi and I have taken up this matter and I have unfortunately become the victim of the Delhi Improvement Trust (Lall, 1952: 3186).

The archives show a steady growth in the Delhi case details. Discussions regarding slums in other cities, even big cities like Mumbai, Kolkata, or Chennai, made it to the floor only on rare occasions. This scrutiny aided the Delhi bias in two ways. Firstly, the Government was pushed to gather data to be able to discuss such matters. Secondly, it illustrated various issues and nuances of the Delhi slums. Answering a question about data on slums, the then Minister of Works, Housing, Supply, and Rehabilitation replied:

No statistics in regard to the number of houses in areas declared as 'slum areas' are available. In Delhi, during the last three years, according to the information furnished by the Municipal Corporation of Delhi, 705 houses and 28 jhuggis in areas notified as slum area were demolished and 3212 families were resettled (Mishra, 1978: 60).

Note that the data non-availability of other states (where slums were not under the Central Government) were put alongside detailed figures from Delhi (where slums were under the Central Government). This data bias aided in painting the Delhi slum as a typical Indian slum. Similar to Connell's (2014) argument, the institutional structure, via Central Government's prerogative over Delhi slums and not the slums from other cities, led to the production of a knowledge base exclusively from Delhi to be rendered universal. Alongside, the details of Delhi cases kept growing, e.g., during a debate of public land encroachment in Delhi, the Minister of Urban Development replied:

... Municipal Corporation of Delhi has reported that one person had encroached upon a part of the footpath measuring... (Nallasivan, 1993: 237). 
Not only did Rajya Sabha discuss minor incidences (such as the encroachment of one person in the above quote), but questions pertaining to Delhi were framed by naming specific locations/neighbourhoods. e.g.:

whether residents of Chittaranjan Park, New Delhi took out a procession on the 29th November, 1992 against illegal construction... (Singh, 1992: 680).

whether it is a fact that the plot in between Aravali and Mandakani Enclave was earmarked for a 'Community Centre' and... (Mishra, 1993: 227).

These details started building a comprehensive picture of the Delhi issues and due to the lack of such details from other cities, the Delhi slum became a reference point. Over time, the issues of Delhi slums became the basis for conceptualizing the Indian slum and experiences from other cities were to verify and strengthen this conceptualization. Therefore, as Chakrabarty (2000) had argued regarding Europe, the Delhi slum became the typical slum, against which all other slums were to be discussed. This typical slum, further, became the basis for legislation and policies, asserting its hegemony and marginalizing cases and issues from rest of the country.

\section{Neoliberal funding phase-1996-2014}

In 1988, the National Commission on Urbanization (NCU) presented its report to the Rajya Sabha. The report provided a conceptual outline and a vision to urbanization in India (Kundu, 1989). The NCU framed the cities as engines of economic growth. This shifted the attitude of the government towards slums. Spending on slums changed its course from being grants for betterment to being investments for returns.

The slum issues shifted from being social, to that of economic ones. This pushed the Central Government to fund slum improvements directly rather than via block allocation of funds to the states as was the case in the previous era. In 1996, the National Slum Development Programme (NSDP) was introduced as a tool to channel this fund. NSDP was applicable to slums across India. The funds were allocated towards sanitation (the main focus), education, housing (small component), healthcare, etc.

As the funding of slum improvement was now for fuelling economic growth, the qualitative cases from Delhi were not enough and a national-level quantitative idea of slums was required. After more than five decades of independence, in 2001, slums were included in the census data. The economic growth became the intent behind quantitative knowledge production about slums, and this knowledge was geared towards structuring investments. However, we will see below, how the geographical factors brought the Delhi bias back, even when slums were being quantified nationally. 
Juxtaposing census data and the NCU report presented a quantitative understanding of the deteriorating state of cities as well as the need to invest and improve, for economic growth. Consequently, the Central Government launched Jawaharlal Nehru National Urban Renewal Mission (JNNURM) in 2005. NSDP was discontinued and was merged into Integrated Housing and Slum Development Programme (IHSDP) and Basic Services to the Urban Poor (BSUP), both subprogrammes of JNNURM (initially accorded a \$20 billion budget over seven years).

As Mahadevia (2006) pointed out, JNNURM saw every Indian City with the same lens, and I would further add that this lens was borrowed from Delhi. In 2003, two years before the launch of JNNURM, Delhi won the bid to host the 2010-Commonwealth-Games. Hosting the games resulted in two main features leading to further Delhi bias. The first feature was the development of a mechanism, which would allow for fast restructuring of the city without legal and bureaucratic hurdles to prepare for the games. It was achieved by having a programme structure premised on a broad vision which was then broken down into executable projects that could be monitored effectively. The second feature was a (re)branding of the city as 'world-class', which, nevertheless, was not limited to Delhi or Indian cities alone. Both these aspects have had a huge impact on the structure of JNNURM. JNNURM was initially conceptualized due to the larger quantitative understanding of slum situations in India (via Census, 2001); however, the institutional framework was copied from Delhi yet again.

The programme structure used for the Commonwealth games was reproduced by JNNURM and called it the City Development Plan (CDP). JNNURM required cities to make CDPs, which as opposed to the traditional master plan, had no statutory bearing, thus, required no public consultation - a process which was much needed to finish the time-bound projects for Commonwealth games in Delhi. The CDP structure in Delhi was possible, only due to an existing density of consultants who drew out the plans. This Delhi-based competence was later transferred to other cities, which reinforced the earlier bias by building CDPs which were essentially copies of the Delhi projects. CDPs as Kundu (2014: 628) discussed, 'became a mere mandatory requisite to avail JNNURM funds'. Furthermore, Kundu and Samanta (2011) have shown that JNNURM benefitted only the big cities in developed Indian states.

The second factor which involved making Delhi a world-class city, resulted in massive slum demolitions in Delhi. As discussed previously, the politics of global image and of being world-class, mandated a slum-free city. Such massive demolitions of Delhi slums caught both national media attention and academic interest (Baviskar, 2013; Bhan, 2016; Ghertner, 2015). This happened along with the mounting critique of corruption after the Commonwealth-Games were over in 2010 resulting in corruption charges were levied and politicians were prosecuted. Yet again, the typical slum of India was pictured from the experience of Delhi—being demolished for corporate greed, citizens thrown 
out of the city from the land they lived on for decades, and the undemocratic process of city building via CDPs.

Exclusively focusing on slums, in 2011, the Central Government formulated, the Rajiv Awas Yojana (RAY). The following two core strategies of the RAY were built around the postCommonwealth-Games idea of Delhi slums: (i) As slums were demolished and citizens shunted out of Delhi, the RAY mandated property rights to slum dwellers in-situ, as championed by de Soto (2002); (ii) As CDPs were solely project-based without public consultation; the RAY mandated a compulsory participatory module. Based on Rajya Sabha debates, it can be concluded that property rights were seen as the silver bullet for making India slum-free (Bhattacharya \& Goyal, 2013).

Property rights have been discussed at length in the Indian context. Mahadevia (2010) in her work showed the nuances for garnering property rights and the inefficacies of imparting it from the top down. This is also partially because of the complex nature of landownership legalities in India, as illustrated by Mukhija (2002) drawing from a Mumbai case. Contrarily, as we discussed previously, Delhi slums were mostly on Government land which was acquired for development. Thus, it made sense for slums to be developed in-situ with property rights in Delhi. Thus again, the Delhi case was adopted for framing the RAY, India's largest slum upgradation programme.

\section{Conclusion}

In this article, I discussed how post-independence, slum-related legislation and policies in India have had a Delhi bias. The focus was on how cases from Delhi slums were used to formulate policy frameworks for slums across the nation. This was a result of the specificity of Delhi with respect to its geographical, socio-political, and historical progression in India. Through pointing to the hegemony of Delhi in knowledge production about slums, the article attempted to shift southern theory to discuss hegemony within the periphery and ordinary city discussions to acknowledge the role of the city behind a regional hegemonic model.

The global-scale concerns of southern theory and ordinary city discussions emanate from a privileged position of the metropolis. This global frame, although important, needs to be scaled and developed within/from the periphery as well. This intent also critiques how the narrative from the global south needs to fit in the larger metropolitan narrative (Chakrabarty, 2000). This is specifically true of discussions surrounding 'slum-free' or 'world-class' cities, that point to the metropolitan bias of what it means to be urban and illustrates how being slum-free becomes part of this narrative. However, when the narratives are provincialized, we encounter a peripheral power dynamics between cities, as shown by the appropriation of slum knowledge from within (Delhi). Here, the claim that slums are demolished as they do not fit the metropolitan urban image is nuanced, by highlighting how 
ideas of the slum are in itself produced via processes within the periphery. As slums do not have universal imagery idealizing them, the inquiry into abstraction of existing slums within a region revealed herein the provincial model of knowledge hegemony or to use Bunnell and Maringanti's (2010: 417) phrase- 'the parochialism of "global" urban practice'.

The Delhi-bias thesis could itself be subjected to further problematization by incorporating the question of positionality. To render Delhi as the peripheral model and to argue towards shifting the theoretical locus, one has to stand in the metropolis. However, with the Delhi-bias thesis, I too perhaps have positioned myself in the metropolis of the periphery. The point is to problematize the article's argument further, to have multiple confrontations and to provincialize further, rather than having fixed loci. Situating slum discussions within larger Asian century aspirations, Roy (2014: 148) has argued that 'In the time of the Asian Century, as urban futures are imagined as Asian futures, such aporias are being reformatted in new paradigms of hegemony and a new politics of poverty'. Reading this hegemony with Chakrabarty's (2000) point of making yet another episode in the global storyline, presents a continual task of encountering such narratives. To perpetually position and develop what Sheppard et al. (2013: 897) has called the 'distinct precarious loci of enunciation', i.e., to avoid constructing a story from the periphery to fit the metropolitan narrative and to provincialize the debates of knowledge hegemony, by decentring Euro-American situatedness. For this article, the locus was slum legislation and policies in India, but it certainly needs to shift to other aspects of the urban. This article is a modest attempt to mobilize the essential principle of southern theory and ordinary city debates, i.e., the project of critiquing knowledge hegemony.

\section{Acknowledgement}

This paper has greatly benefited from discussions with Prof. Haripriya Rangan during the archival analysis. I would also like to thank Prof. René Véron for his insightful comments on an earlier version of this paper. The research for this article was funded by Swiss National Science Foundation (Grant number 171860). The fieldwork for this research was funded by the University of Lausanne.

\section{References}

Amin A, Graham S (1997) The ordinary city. Transactions of the Institute of British Geographers 22 (4), 411-29.

Arabindoo P (2011) Rhetoric of the 'slum': Rethinking urban poverty. City 15 (6): 636-46.

Ballabh Pant G (1956) The Slum Areas (Improvement and Clearance) Bill, 1956. Rajya-Sabha Debates. Available at: http://rsdebate.nic.in/handle/123456789/575530 (accessed 14 January 2015).

Baviskar A (2003) Between violence and desire: space, power, and identity in the making of metropolitan Delhi. International Social Science Journal 55 (175), 89-98. 
Baviskar A (2013) Spectacular events, city spaces and citizenship: The commonwealth games in Delhi. In Anjaria JS, McFarlane C (eds) Urban Navigations, 152-76. Routledge, India.

Berner EJ (2000) Poverty alleviation and the eviction of the poorest: Towards urban land reform in the Philippines. International Journal of Urban and Regional Research 24 (3), 554-66.

Bhan G (2013) Planned illegalities-Housing and the 'failure' of planning in Delhi: 1947-2010. Economic and Political Weekly 48 (24), 58-70.

Bhan G (2016) In the Public's Interest: Evictions, Citizenship and Inequality in Contemporary Delhi. Geographies of Justice and Social Transformation Series 30. University of Georgia Press, Georgia.

Bhattacharya P, Goyal P (2013) Slum population in the country. Rajya-Sabha Debates. Available at: http://rsdebate.nic.in/handle/123456789/624824 (accessed 25 February 2015).

Bunnell T, Maringanti A (2010) Practising urban and regional research beyond metrocentricity: Research beyond metrocentricity. International Journal of Urban and Regional Research 34 (2): 415-20.

Chakrabarty D (2000) Provincializing Europe: Postcolonial Thought and Historical Difference. Princeton University Press, Princeton, NJ.

Chanda A (1958) The Public Premises (Eviction of Unauthorized Occupants) Bill, 1958. Rajya-Sabha Session 20. Available at: http://rsdebate.nic.in/handle/123456789/570395 (accessed 14 January 2015).

Chatterji R (2005) Plans, habitation and slum redevelopment: The production of community in Dharavi, Mumbai. Contributions to Indian Sociology 39 (2), 197-218.

Comaroff J, Comaroff JL (2012) Theory from the South: Or, How Euro-America Is Evolving toward Africa. Paradigm Publishers, Boulder, Colorado.

Connell R (2011) Southern Theory: The Global Dynamics of Knowledge in Social Science. Reprinted. Polity Press, Cambridge.

Connell R (2014) Using southern theory: Decolonizing social thought in theory, research and application. Planning Theory 13 (2), 210-23.

Das PK (2003) Slums: the continuing struggle for housing. In Patel S, Masselos J (eds) Bombay and Mumbai, the City in Transition, 207-34. Oxford University Press, New Delhi.

Datta A (2012) The Illegal City: Space, Law and Gender in a Delhi Squatter Settlement. Gender, space and society. Ashgate, Farnham.

de Satgé R, Watson V (2018) Implications for southern planning theory and practice. In de Satgé R, Watson V Urban Planning in the Global South, 187-219. Springer International Publishing, Cham.

de Soto H (2002) The other path: the economic answer to terrorism. Basic Books, New York.

Dembowski H (2001) Taking the State to Court: Public Interest Litigation and the Public Sphere in Metropolitan India. Oxford University Press, New Delhi, Oxford.

Dhage VK (1960) Prime Minister's letter to Chief Ministers of States about the development of cities. Rajya-Sabha Debates. Available at: http://rsdebate.nic.in/handle/123456789/562101 (accessed 14 January 2015).

Dupont V (2008) Slum demolitions in Delhi since the 1990s: An appraisal. Economic and Political Weekly 43 (28), 79-87.

Ghertner DA (2015) Rule by Aesthetics: World-Class City Making in Delhi. Oxford University Press, New York. 
Gilbert A (2007) The return of the slum: Does language matter? International Journal of Urban and Regional Research 31 (4), 697-713.

Harriss-White B, Olsen W, Vera-Sanso P, Suresh V (2013) Multiple shocks and slum household economies in South India. Economy and Society 42 (3), 398-429.

Huchzermeyer M (2010) Pounding at the tip of the Iceberg: The dominant politics of informal settlement eradication in South Africa. Politikon 37 (1), 129-48.

Jazeel T (2014) Subaltern geographies: Geographical knowledge and postcolonial strategy. Singapore Journal of Tropical Geography 35 (1), 88-103.

Joshi VU and Kale VS (2013) Environmental Conflicts in Coastal Metropolitan Cities in India: Case Studies of Mumbai and Chennai Metropolitan Regions. In: Khan AZ, Le QX, Canters F, Corjin E. (eds) Environmental Conflicts in Coastal Urban Areas: Towards a Strategic Assessment Framework for Sustainable Development. Sapienza Università Editrice. Rome.

Koster M, Nuijten M (2016) Coproducing urban space: Rethinking the formal/informal dichotomy. Singapore Journal of Tropical Geography 37 (3), 282-94.

Kundu A (1989) National commission on urbanization: Issues and non-issues. Economic and Political Weekly 24 (21), 1185-8.

Kundu D (2014) Urban development programmes in India: A critique of JnNURM. Social Change 44 (4), 615-32.

Kundu D, Samanta D (2011) Redefining the inclusive urban agenda in India. Economic and Political Weekly 46 (5), 55-63.

Lall KB (1952) Recommendations of The Delhi Improvement Trust Enquiry Committee. Rajya-Sabha Debates. Available at: http://rsdebate.nic.in/handle/123456789/590522 (accessed 19 January 2015).

Lawhon M, Truelove Y (2019) Disambiguating the southern urban critique: Propositions, pathways and possibilities for a more global urban studies. Urban Studies.

Legg S (2006a) Governmentality, congestion and calculation in colonial Delhi. Social \& Cultural Geography 7 (5), 709-29.

Legg S (2006b) Postcolonial developmentalities: From the Delhi improvement trust to the Delhi development authority. In Raju S, Kumar MS, Corbridge S (eds) Colonial and Post-Colonial Geographies of India, 184-204. Sage Publications, New Delhi.

Leitner H, Sheppard E (2016) Provincializing critical urban theory: Extending the ecosystem of possibilities. International Journal of Urban and Regional Research 40 (1), 228-35.

Mahadevia D (2006) NURM and the poor in globalising mega cities. Economic and Political Weekly 41 (31), 3399-403.

Mahadevia D (2010) Tenure security and urban social protection links: India. Ids Bulletin-Institute of Development Studies 41 (4), 52-62.

Massey D (1993) Power-geometry and progressive sense of place. In Bird J, Curtis B, Putnam T, Robertson G, Tickner L (eds) Mapping the Futures: Local Cultures, Global Change. Routledge, London.

McFarlane C (2012) Rethinking informality: Politics, crisis, and the city. Planning Theory \& Practice 13 (1), 89-108.

Mishra K (1978) Slums in Metropolitan Cities. Rajya-Sabha Debates. Available at: http://rsdebate.nic.in/handle/123456789/424926 (accessed 3 February 2015).

Mishra SP (1993) Removal of JJ. clusters nearby Aravali Apartment. Rajya-Sabha Debates. Available at: http://rsdebate.nic.in/handle/123456789/182575 (accessed 17 February 2015). 
Mukhija V (2002) An analytical framework for urban upgrading: property rights, property values and physical attributes. In Zhu J, Sim L-L (eds) Institutional Analysis of Asia-Pacific Real Estate Markets. Special Issue, Habitat International 26 (4), 553-70.

Naik M (1958) Slum Clearance Committee. Rajya-Sabha Debates. Available at: http://rsdebate.nic.in/handle/123456789/570654 (accessed 14 January 2015).

Nallasivan A (1993) Illegal encroachment at Manakapura. Rajya-Sabha Debates. Available at: http://rsdebate.nic.in/handle/123456789/182764 (accessed 17 February 2015).

Narayan D (1964) Allotments for Housing Schemes. Rajya-Sabha Debates. Available at: http://rsdebate.nic.in/handle/123456789/542874 (accessed 15 January 2015).

New Urban Agenda (Habitat-III) (2016) United Nations Conference on Housing and Sustainable Urban Development, October. Quito, Ecuador: United Nations.

Palat Narayanan N (2019) The production of informality and everyday politics: Drinking water and solid waste management in Jagdamba Camp, Delhi. City 23 (1), 83-96.

Pandey G (2001) Remembering Partition: Violence, Nationalism, and History in India. Cambridge University Press, Cambridge, New York.

Parnell S, Robinson J (2012) (Re)theorizing cities from the global south: Looking beyond neoliberalism. Urban Geography 33 (4), 593-617.

Patel S (2019) Sociology through a 'South' prism. In Fiddian-Qasmiyeh E, Daley P (eds) Routledge Handbook of South-South Relations, 31-47. Routledge, Abingdon, Oxon; New York, NY.

Patil PD (2009) President's Address to both the Houses of Parliament. Lok-Sabha Archives. Available at: http://164.100.47.194/Loksabha/Debates/Result15.aspx?dbsl=10 (accessed 5 September 2017).

Paul BK (2006) Fear of eviction: The case of slum and squatter dwellers in Dhaka, Bangladesh. Urban Geography 27 (6), 567-74.

Perera N (1998) Society and Space: Colonialism, Nationalism, and Postcolonial Identity in Sri Lanka. Transitions-Asia and Asian America. Westview Press, Boulder, Colorado.

Perlman JE (1979) The Myth of Marginality: Urban Poverty and Politics in Rio de Janeiro. University of California Press, Berkeley.

Radcliffe SA (2017) Decolonising geographical knowledges. Transactions of the Institute of British Geographers 42 (3), 329-33.

Ramanathan U (2005) Demolition drive. Economic and Political Weekly 40 (27), 2908-12.

Rao V (2006) Slum as theory: the South/Asian city and globalization. International Journal of Urban and Regional Research 30 (1), 225-32.

Robinson J (2006) Ordinary Cities: Between Modernity and Development. Questioning cities. Routledge, New York.

Roy A (2014) Slum-free cities of the Asian century: Postcolonial government and the project of inclusive growth. Singapore Journal of Tropical Geography 35 (1), 136-50.

Sheppard E, Leitner H, Maringanti A (2013) Provincializing global urbanism: A manifesto. Urban Geography 34 (7), 893-900.

Sherkhan (1964) Slum Clearance Scheme. Rajya-Sabha Debates. Available at: http://rsdebate.nic.in/handle/123456789/537572 (accessed 15 January 2015).

Singh G (1992) Illegal construction in Chittaranjan Park, New Delhi. Rajya-Sabha Debates. Available at: http://rsdebate.nic.in/handle/123456789/211704 (accessed 10 February 2015). 
United Nations (1976) The Vancouver Declaration on Human Settlements (Habitat-I) From the report of Habitat: United Nations Conference on Human Settlements, 31 May to 11 June, Vancouver, Canada.

United Nations Conference on Human Settlements (Habitat-II) (1996) United Nations Conference on Human Settlements, June. Istanbul, Turkey: United Nations.

Watson V (2009) Seeing from the South: Refocusing urban planning on the globe's central urban issues. Urban Studies 46 (11), 2259-75.

Weinstein L (2008) Mumbai's development mafias: Globalization, organized crime and land development. International Journal of Urban and Regional Research 32 (1), 22-39. 